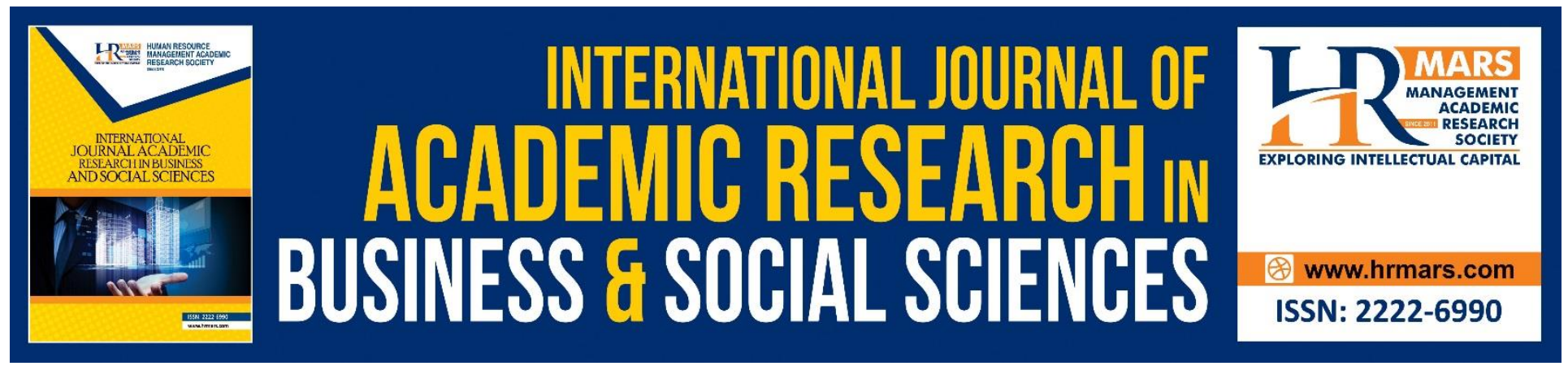

\title{
Repositioning of Spa Premises into the Context of Islamic Built Environment and Muslim Friendly Attributes
}

Rashidi Othman, Nur Fadhlina Mohd Noor, Khairusy Syakirin Has-Yun Hashim, Nurliyana Ahmad, Nurwina Aishah Manan, Lukman Hakim Mahamod and Nurrulhidayah Ahmad Fadzillah

To Link this Article: http://dx.doi.org/10.6007/IJARBSS/v9-i2/5660

DOI: $\quad 10.6007 /$ IJARBSS/v9-i2/5660

Received: 02 Jan 2019, Revised: 05 Feb 2019, Accepted: 25 Feb 2019

Published Online: 26 Feb 2019

In-Text Citation: (Othman et al., 2019)

To Cite this Article: Othman, R., Noor, N. F. M., Hashim, K. S. H.-Y., Ahmad, N., Manan, N. A., Mahamod, L. H., \& Fadzillah, N. A. (2019). Repositioning of Spa Premises into The Context of Islamic Built Environment and Muslim Friendly Attributes. International Journal of Academic Research in Business and Social Sciences, 9(2), 1014-1023.

Copyright: (C) 2019 The Author(s)

Published by Human Resource Management Academic Research Society (www.hrmars.com)

This article is published under the Creative Commons Attribution (CC BY 4.0) license. Anyone may reproduce, distribute, translate and create derivative works of this article (for both commercial and non-commercial purposes), subject to full attribution to the original publication and authors. The full terms of this license may be seen at: http://creativecommons.org/licences/by/4.0/legalcode

Vol. 9, No. 2, 2019, Pg. 1014 - 1023

Full Terms \& Conditions of access and use can be found at http://hrmars.com/index.php/pages/detail/publication-ethics 


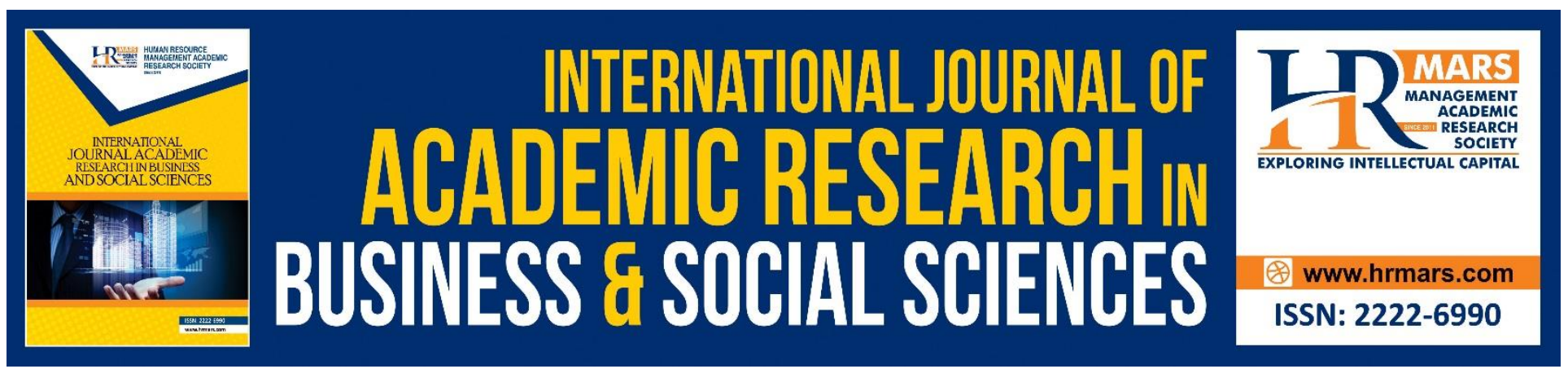

\title{
Repositioning of Spa Premises into The Context of Islamic Built Environment and Muslim Friendly Attributes
}

\author{
Rashidi Othman, Nur Fadhlina Mohd Noor, Khairusy Syakirin Has- \\ Yun Hashim, Nurliyana Ahmad, Nurwina Aishah Manan, Lukman \\ Hakim Mahamod and Nurrulhidayah Ahmad Fadzillah \\ ${ }^{1}$ International Institute of Halal Research and Training (INHART), \\ Department of Landscape Architecture, Kulliyyah of Architecture \& Environmental Design, \\ International Islamic University Malaysia, Jalan Gombak, 53100 Kuala Lumpur, Malaysia.
}

\begin{abstract}
Spas have become increasingly popular and have emerged as important profit centers for hotels. However, the uniqueness of this market has been largely overlooked in term of Shari'ah compliant to cater to Muslim needs. Therefore, the purpose of this study is to the repositioning of spa typologies, spatial organization and social interaction in the context of Islamic built environment. A survey was administered at 4 case studies of different spas typologies in Kuala Lumpur and Selangor to identify the new dimensions of Muslim-friendly spa concept. Cluster analysis was then applied to classify spa premises into different groups based on the typologies, services and spatial organization. Finally, the importance analysis was performed according to the groups to determine significant Shari'ah compliant or Muslim-friendly elements. Based on the finding, the spa that follows the Shari'ah compliance brings remuneration and advance the excellence of spa by implementing space organization of spa, which is considering security, privacy, also a segregation gender in space including the spa design component. It is crucial that Malaysia takes concrete steps to develop Islamic or Shari'ah compliant tourism internationally. This research is intended to provide further information on the understanding, practice, features, and requirements for Muslim-friendly spa which will help to boost Malaysia's potential to become as one of the prominent destinations for Islamic or Shari'ah compliant tourism.
\end{abstract}

Keywords: Spa, Islamic Built Environment, Muslim Friendly, Maqasid Shariah

\section{Introduction}

Malaysia is one of the Muslim countries in Southeast Asia that received billions of tourists from across the world (Islamic Tourism Centre, 2018). Spa industries have become an important profit center for 
hotels increasingly (Foster, 2016). Muslim-friendly spas are now emerging due to the demand among Muslim women and for the needs of Muslim woman to cover their awrah (covering all parts bodies except face and hand) even in front of the non-Muslim woman (Yaman et al., 2012). The formation of hospitality such as Shari'ah compliant hotels, halal restaurants, halal food, gender segregation in the use of facilities and services, which perform, based on the religious law could claim as "Muslim Friendly" (Mat Som et al., 2016). Despite that, every woman wanted to be beautiful and healthy after they have realized the existence of the spa, where spa believes in helping boost the well-being of a person from the inside. Besides, they are looking for a spa premise that has Maqasid Shari'ah where they can beautify themselves as well as cover their awrah. Therefore, the demand for Islamic spa concept is increase when users realize the importance of a healthy lifestyle (Othman et al., 2015). Spa treatments are an operation or service that involves three important aspects of healing a smooth life. That is the quality aspect of daily life, the pleasure of self-care and the element of a live action for a sparkling life (Henry and Taylor, 2005). There are a few types of spas in the industry of beauty and health as detailed by ASEAN Spa Standard (2016):

i. Day spa - it takes about 1-5 hours of treatment or maybe a day. This type of spas can be found in shophouses, shopping centers, or at an airport. The availability of accommodation is not provided; ii. Club spa - the spa is located in a club where membership is paid, and only those can get the service. It is focusing in strengthen the body, including yoga and other treatments. No services are provided to visitors;

iii. Hotel or resort spa - spa inside the hotel or resort. Offering its first services such as massage, sauna, steaming, and exercise. Since it is located inside the hotel, most of its customer is the guest that stays in the hotel or resort. Accommodation is not available in this type of spa;

iv. Mineral Spring spa - a natural or artificial hot spring spa or mineral spring spa that gives healing waters as benefits to anyone who uses it. This type of spa is considered as a recreation place, and there are some of this mineral spring spa is developed into the resort;

v. Cruise Ship spa - Located on a cruise ship that provides beauty treatment services as well as pampering, also offers a place to do training or other activities for health; and

vi. Destination spa - a full set of treatment provided in this spa. It served its customer with customized lifestyle. Their aim is to improve the lifestyle through various activities and services such as a guide to proper living lifestyle and balanced diet. Accommodation is provided in this type of spa, along with services on spa cuisine and healthy food.

Islamic Spa Practice standards by Malaysia Islamic Development Department (MIDD) outlined the guide and attraction of Islamic spa concept that is to give treatment and services by segregate the genders (Yaman et al., 2012). The aim of this research is to the repositioning of spa typologies, spatial organization and social interaction in the context of Islamic built environment. This research will focus on the current tourism spa premises and how the Islamic built environments principles can be integrated with the design and the services of the premises.

\section{Methodology}

On-site Observation

On-site observation is done to study the design elements, spatial organization and social interaction of the spa. Information is obtained through observation and case studies in an existing spa that may 
or may not follow shari'ah compliant regulations. Four case studies were selected based on types and scale of the spa, namely Ayur-V Hair and Beauty Salon, Gombak; Lanna Thai, Mandara spa, and Anggun spa, Kuala Lumpur. Ayur- $V$ and Lanna Thai spa were selected because these two spas fall under the category of the day spa and it operates in shop lots area and does not offer accommodation to the guest. Therefore, these spas fit the criteria needed for this research.

On the other hand, Mandara spa and Anggun spa were selected because these spas operate under hotel services and management where it offers service such as sauna and massages without accommodation offered. As for the Mandara spa, it is located inside the Sheraton Hotel, meanwhile, Anggun spa is located inside the Maya Hotel. All the selected sites mentioned above were known to have its own significant remarks. For this research, participant observation was selected, where multiple ways of gaining data were used in order to collect data from participants (Taylor et al., 2009). The researcher also underwent the treatment offered in the spa to understand more on the issues and challenges for a spa premise in the context of Islamic built environment according to three aspects: 1) service and management, 2) social interaction and 3) spatial organization of the spa.

Interviews

The interviews were conducted with experienced individuals from design backgrounds based on the individual's design solution tactics, opinions, space planning and layout ideas. The interview also was conducted with the Mufti Wilayah (Islamic State Counselor) in order to get an opinion from him regarding spa premises from the Islamic perspectives.

Secondary Data

Secondary data was collected through different means and sources, that are taken directly or indirectly from books, journals, reports, articles and guidelines. This method is used throughout the study period. The documents are used as preliminary study as to get an overview of the subject studied, then being used again to strengthen and complement the data acquired from interview and observation conducted.

\section{Data Analysis}

The process of collecting data for inventory and data analysis was done during the site visit. A checklist was prepared before going to the site to ensure all the primary data needed were covered. After the checklist was updated and recorded, the collected data were analyzed in details, and the results were presented accordingly. The data was analyzed based on the maqasid shari'ah principles which include three stages of human welfare namely: 1) dharuriyyah (necessity), 2) hajiyyah (needs) and 3) tahsiniyyah (complimentary).

\section{Data Analysis and Discussion}

Based on the findings conducted at the sites, observation and interview data were gathered from two different types of spa - day spa and hotel or resort spa. Each spa had a different theme and concept. Thus, it has a different layout and composition. There are some issues and challenges at the spa premises regarding the services and management, social interaction between staff and guest and spatial organization of spas in fulfilling it to the Islamic Built Environment context. As for Ayur $-\mathrm{V}$, the spa had an Indian theme that offers Indian treatment called Ayurvedic. This spa was claimed as Muslim-friendly spa by them, whereby they gave treatment for Muslim women and had a curtain as a barrier to cover their guest awrah. To understand more the services and management, researchers 
had undergone the treatment, to experience the social interaction that happens during treatment time. From the observation, the curtain in the treatment area for covering the awrah of Muslim women cannot completely cover the guest awrah, as the curtain was quickly opened by others. Thus, the waiting and treatment area in the premise does not segregate their area by genders. This does not guarantee the privacy of the guest and not a promising Muslim friendly spa. Figure 1 showed the plan for the spa premises with the area in the red box was the most used area for daily treatment such as washing hair, threading, and massage.

Figure 1: Floor plan for inventory and analysis of Ayur - Vspa

Also, behind the treatment area was the space utilized by staff to rest and waiting area located in front of the treatment area caused the area too congested during their peak hour. As for the washroom, it was not separated between staff and guest and was not well maintained. This showed that the need for a proper composition between the treatment area and waiting area will lead to a more organized spatial organization.

The next spa case study was Lanna Thai located at Kuala Lumpur. This spa offered Thailand theme with significant traditional Thai massage. Lanna Thai spa had a communication problem between staff and guest. The procedures for getting treatment were inadequate as there was no consultation beforehand with the guest. Interestingly the therapists were segregate by genders upon request. The cleanliness of the spa was acceptable and could be enhanced. Lanna Thai spa provided Thailand theme music for guest entertainment to feel calm as they enter the premise and while waiting for their turn. Figure 2 established that Lanna Thai spa consists of the treatment area, waiting and reception area. From the observation, the main issues of the spatial organization of Lanna Thai were the treatment area was exposed to other guests as well as no sufficient space for guest at the waiting area. These challenges occurred because of the limited space inside the spa. Therefore, these make the spa less privacy and not Muslim friendly. 


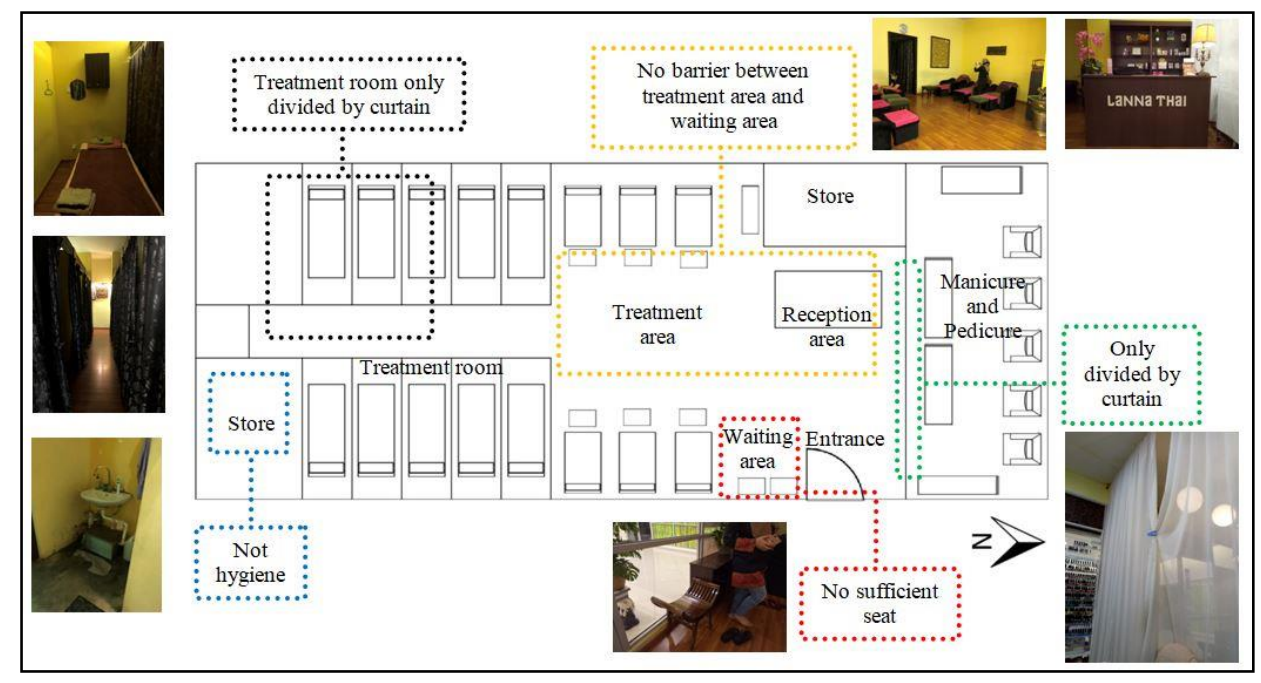

Figure 2. Floor plan for inventory and analysis of Lanna Thai Spa

Figure 3 and Figure 4 demonstrated a hotel or resort type of spa with Balinese treatment to its guest. For both spas, the services and management are well organized, starting from the moment a guest entered the spa until the guest ended up the treatment. There were consultation forms before a guest commenced any treatment. The spa staffs were friendly and cooperative in giving information in regards to their spa. However, the service in Anggun spa, Hotel Maya was not as good as Mandara spa due to lack of staff as well as no segregation between male and female during the treatment. In contrast, Mandara spa had separated treatment area for genders, where the female therapist will only give treatments to female guest and vice versa. Through this, the awrah of the guest are well protected, and Shari'ah compliant. Also, the composition of the layout was well arranged, where the waiting area and treatment area are well separated. Treatment area offered an area with six treatment room includes single room and couple room, this enough to cater guest from hotel and guest from outside. This showed that although Mandara spa was not claimed as Muslim-friendly spa, the management controlled the social interaction of therapists and guest to maintain their reputation as 5 -star hotels. 


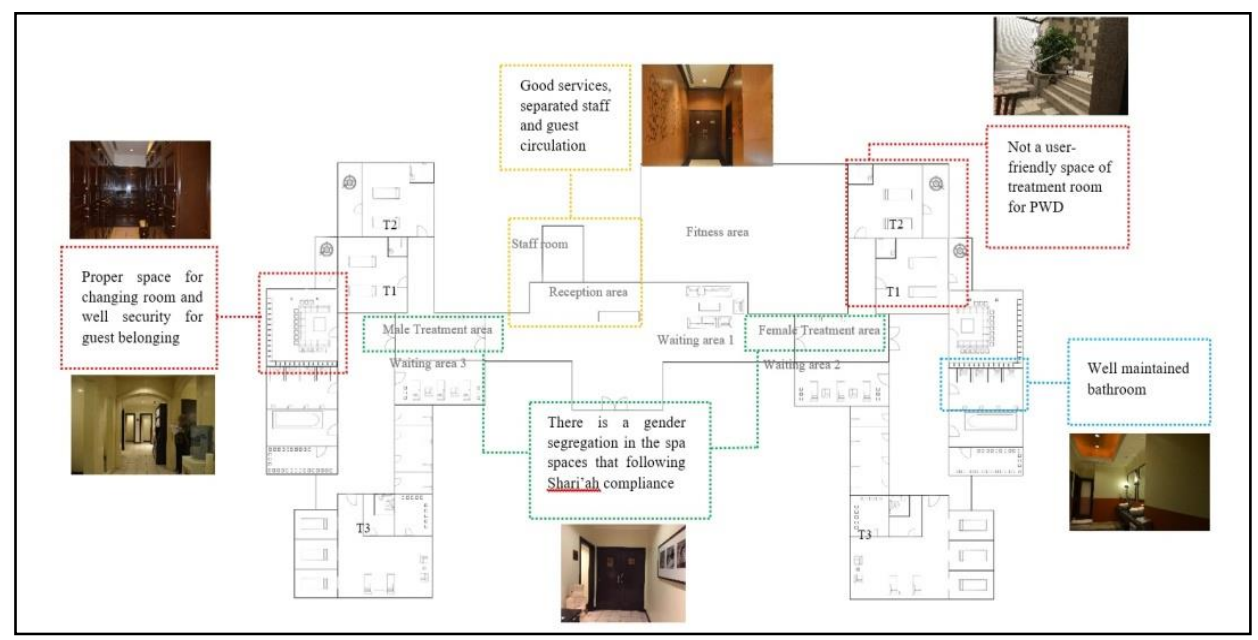

Figure 3. The outdoor and indoor layout of Sungai Sireh Homestay

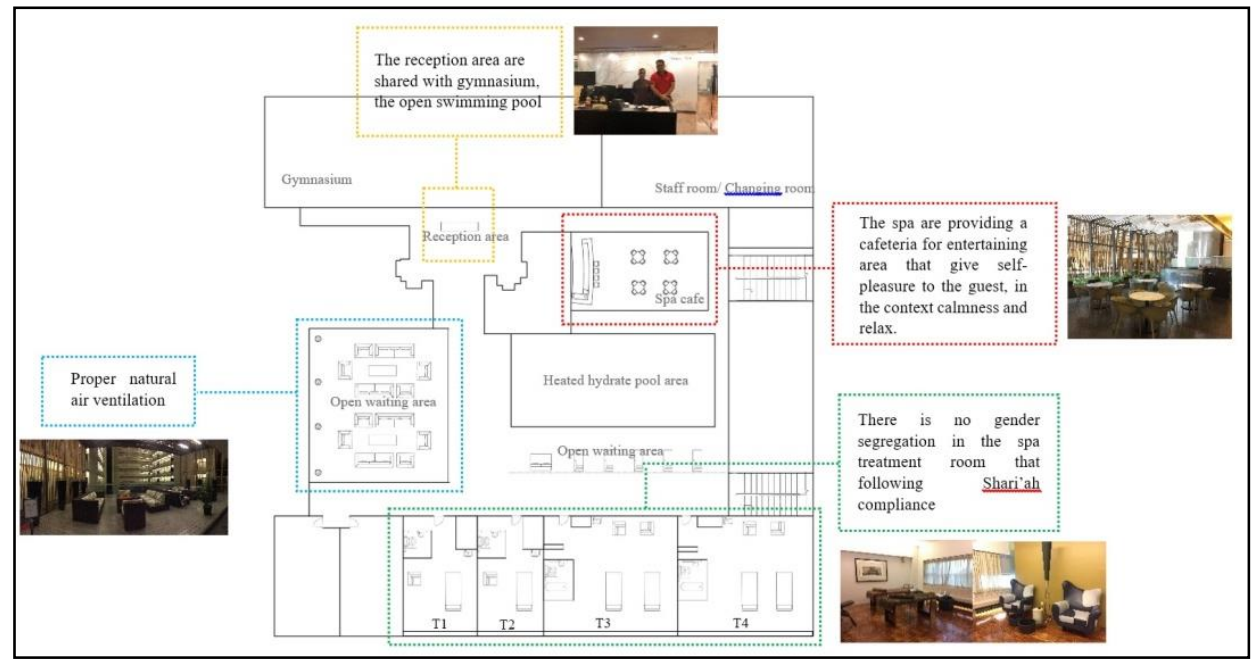

Figure 4. Floor plan for inventory and analysis of Anggun spa, Hotel Maya

Figure 4 indicated that the area in the blue box was the center of the spa, where an open waiting area took place. In the yellow box, the reception area for Anggun spa was separated with waiting area, but the reception for gymnasium and spa were combined. The treatment rooms are highlighted in the green box, where all treatments such as massage, scrub, and sauna are provided. Lastly, in the red box, a café provided for guest to rejuvenate their mind.

Tables 2 sum up three main aspects of services and management, social interaction and spatial organization that related to Muslim friendly attributes or comply to Shariah between Ayur - V spa, Lanna Thai spa, Mandara spa, Sheraton Hotel and Anggun spa, Maya Hotel. 
INTERNATIONAL JOURNAL OF ACADEMIC RESEARCH IN BUSINESS AND SOCIAL SCIENCES

Vol. 9, No. 2, Feb, 2019, E-ISSN: $2222-6990$ ๑ 2019 HRMARS

Table 2: Islamic Built Environment issues and challenges

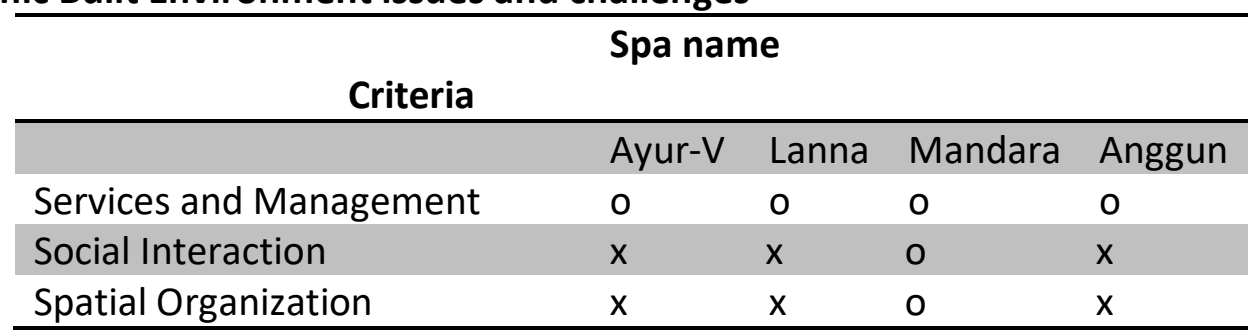

Our findings on all case studies identified that Mandara spa in Sheraton Hotel is more Muslim friendly compared to others due to the excellent environment inside and outside the spa. In short, the interview had been done to further understands the context of Muslim-friendly spa. The findings from the interview session with Mufti Wilayah (Islamic State Counselor) can be summarised as stated in Table 3.

Table 3: Data from the interview session

\begin{tabular}{|l|l|}
\hline \multirow{4}{*}{$\begin{array}{l}\text { Data from the } \\
\text { interview session }\end{array}$ the } & $\begin{array}{l}\text { The spa allows for medical purposes } \\
\text { The layout of the spa should be divided by } \\
\text { gender. }\end{array}$ \\
& $\begin{array}{l}\text { Spa premise is permissible if it follows Islamic } \\
\text { guidelines }\end{array}$ \\
\hline
\end{tabular}

\section{Conclusion}

As a conclusion, the Muslim-friendly spa premises that shari'ah compliant can be implemented to support the Muslims tourists' needs in repositioning the spa premises according to the three main aspects, i) Services, ii) Social Interaction and lastly, iii) Spatial Organization. In addition, the spa that follows the Shari'ah compliant brings benefits and improved the quality of the spa. Thus, every service offered to the guest as well as the products and ingredients of the substance used during a spa treatment are all shari'ah compliant and Muslim friendly. Technically, the concept of privacy in Islam is divided into four. The first one would be the segregation gender in space, this means that segregation for gender in a particular area is needed to avoid harm to other family members, especially from strangers. The second point is security and safety that referring to the awrah that needs to cover from another gender perspective. The third point is privacy elements which could be achieved through two elements namely, i) visual privacy - privacy in terms of perspectives and ii) acoustic privacy - from the privacy of sound. Last but not least, is the architectural or design component or the need for privacy from all surroundings in the architectural building. It is also recommended that each spa premises emphasizing the hygiene and safety measures, as a way to improve the quality of the premises. Islam states that cleanliness (nazhofah) is part of the faith. On top of that, the spa premises should provide facilities such as musolla, to enable its Muslim clients to fulfill their obligations. In addition, equipment for the disabled should also be emphasized as a userfriendly space, for example, ramps, braille and special bathrooms as they also wanted to experience beauty treatments at the spa. 
INTERNATIONAL JOURNAL OF ACADEMIC RESEARCH IN BUSINESS AND SOCIAL SCIENCES

Vol. 9, No. 2, Feb, 2019, E-ISSN: 2222-6990 C 2019 HRMARS

\section{Acknowledgement}

This work was supported by the Ministry of Higher Education (MOHE) and International Islamic University Malaysia (IIUM) under Research Grant MOHE18-001-0001

\section{Corresponding Author}

Assoc. Prof. Dr. Rashidi Othman

International Institute of Halal Research and Training (INHART), KAED, International Islamic University Malaysia, Jalan Gombak, 53100 Kuala Lumpur, Malaysia.

Email: rashidi@iium.edu.my

\section{References}

Othman, R., Noor, N. F. M., Hashim, K. S. H.-Y., Ahmad, N., Manan, N. A., Mahamod, L. H., \& Fadzillah, N. A. (2019). Repositioning of Spa Premises into The Context of Islamic Built Environment and Muslim Friendly Attributes. International Journal of Academic Research in Business and Social Sciences, 9(2), 1014-1023.

Ahmad Sakarwi, A., Abdullah, A., Md. Dali, N., MohdKhazani, N. A. (2017). The Philosophy of Maqasid Al-Shari'ah and Its Application in The Built Environment. Journal of Built Environment, Technology and Engineering.

ASEAN Spa Services Standard 2016. Southeast Asia, pp 1-136.

Cohen. M. (2008). "Spa, wellness and human evolution", Understanding the global spa industry, pp 3-25.

Foster, A., (2006). Hotel Spas as Independent Profit Centers.

Available from:https://www.hospitalitynet.org/opinion/4026556.html [Accessed 23rd March 2018].

Garrow. J. (2008). "Spa industry benchmarking”, Understanding the global spa industry, pp 53-65.

Henry R. D. and Taylor J. D. (2005). Spa: The Sensuous Experience.

Islamic Tourism Centre of Malaysia (2018) Growing the Islamic Tourism Sector with You. Available at: http://www.itc.gov.my/industry/ [Accessed 30th March 2018].

Mat Som, A.P., Satoshi, M., Ahmad, M.F. (2016). The Growth of Muslim Friendly and Halal Tourism in Inbound \& Outbound Travel Market, A Macrotheme Review, A Multidisciplinary Journal of Global Macro Trends, 10-17.

Noorul Huda, M. R., Anuar, T. (2013). The Concept of Privacy and The Malay Dwelling Interior Space Planning, AMER International Conference on Quality of Life. Procedia-Social and Behavioral Sciences 101(2013), 404-414. 
INTERNATIONAL JOURNAL OF ACADEMIC RESEARCH IN BUSINESS AND SOCIAL SCIENCES

Vol. 9, No. 2, Feb, 2019, E-ISSN: 2222-6990 C 2019 HRMARS

NorlizabintiMohd Isa. (2011). A methodology to elicit the perceptions of experts on the meaning of Islamic Built Environments in Malaysia. Cities Design And Planning With People's Perception Consideration, 1-14.

Othman, R., Abdul Halim, S.F.A., Hashim, K.S.H., Baharuddin, Z.M., and Mahamod, L.H. (2015). The emergence of Islamic spa concept, Advanced Science Letters, Vol. 21, 1750-1753.

Spahic, O. (2002S). Studies in the Islamic Built Environment. Kuala Lumpur: Research Centre, International Islamic University Malaysia.

Tabbacci. M. (2008). "American and European spa”, Understanding the global spa industry, pp 2640.

Tawil, R., F. (2011). Classifying the Hotel Spa Tourist: A Multidimensional Qualitative Approach, International Journal of Humanities and Social Sciences.

Taylor, B., Sinha, G., Ghoshal, T. (2009). Research Methodology A Guide for Researchers in Management \& Social Sciences, 4th Edition, New Delhi, Eastern Economy Edition.

The Oxford Dictionary of English. Available at: https://www.oxforddictionaries.com/ [Accessed 30th March 2018].

Utaberta, N. (2008). Perbandingan Idea danPemikiranSenibina Islam.

Yaman, R., Alias, Z., Mohamed Ishak, N. (2012). Beauty treatment and spa design from an Islamic perspective, Procedia - Social and Behavioral Sciences, 492-501.

MaqasidSyariah [online] Available at: http://drhalimi.blogspot.my/2014/03/maqasidsyariah.html [February]

PerbezaanSyariahdanFiqh. Available at: https://syedosram.blogspot.my/2010/01/perbezaansyariah-dan fiqh.html [Accessed 28th March 2018]. 